\title{
Catalytic Efficiency of Acidithiobacillus ferrooxidans for Bioleaching Copper from Chalcocite Containing Sulfide Ore from Reko Diq Deposits
}

\author{
Muhammad Ali Furqan', Uzma Farooq ${ }^{2}$, Rabia Liaquat ${ }^{3}$, Huda Ahmed Alghamdi ${ }^{4}$, \\ Bashir Ahmad $^{5}$, Zahid Qureshi ${ }^{7}$, Asif Jamal' ${ }^{1}$, Isfahan Tauseef ${ }^{6}$, Syed Kashif Haleem ${ }^{6}$, \\ Inayat Ullah ${ }^{8}$, Muhammad Ishtiaq Ali ${ }^{1 *}$ \\ 'Department of Microbiology, Quaid-i-Azam University, Islamabad, Pakistan \\ ${ }^{2}$ Department of Plant Sciences, Quaid-i-Azam University, Islamabad, Pakistan \\ ${ }^{3}$ Department of Energy System Engineering, National University of Sciences and Technology, Islamabad, Pakistan \\ ${ }^{4}$ Department of Biology, College of Sciences, King Khalid University, Abha, Saudi Arabia \\ ${ }^{5}$ Faculty of Basic \& Applied Sciences, International Islamic University, Islamabad \\ ${ }^{6}$ Department of Microbiology, Hazara University Pakistan \\ ${ }^{7}$ Government College University, Lahore, Pakistan \\ ${ }^{8}$ Department of Zoology, The University of Lakki Marwat Pakistan
}

Received: 10 June 2018

Accepted: 24 September 2018

\begin{abstract}
Bioleaching of low-grade secondary copper sulphide ores using different microbial strains is an ecologically safe technology for the recovery of metals in the mineral and mining industry. The purpose of the present study was to analyze the mineral contents of Reko Diq deposits and to assess the dissolution of copper from sulfide ore by an indigenously isolated strain of acidophilic iron- and sulfur-oxidizing bacterium (BSTFe-2) in shake flask experiments. X-ray diffraction (XRD) analysis of the ore sample suggested that it contained $0.81 \% \mathrm{Cu}$ on dry matter basis and contained chalcocite $\left(\mathrm{Cu}_{2} \mathrm{~S}\right)$ and covellite $(\mathrm{CuS})$ as main copper minerals. Pyrite $\left(\mathrm{FeS}_{2}\right)$ was also present as a sulfide mineral. The other minerals detected in the ore matrix were muscovite (a di-octahedral mica mineral), quartz, feldspar (anorthite) and calcite. Quartz $\left(\mathrm{SiO}_{2}\right)$ was the main silicate mineral present in the sample. Calcite $\left(\mathrm{CaCO}_{3}\right)$ was found as the main acid-consuming gangue mineral. We observed that about $80-90 \%$ of the total $\mathrm{Cu}$ content present in the ore matrix was solubilized during 30 days of the leaching process mediated by Acidithiobacillus ferrooxidans at $30^{\circ} \mathrm{C}$. Copper dissolution from ore was found to be directly related to the reaction $\mathrm{pH}(1.5-1.9)$. The leaching data obtained from the pulp densities $(5,10$ and $20 \% \mathrm{wt} / \mathrm{vol})$ at
\end{abstract}

*e-mail: ishi_ali@hotmail.com 
$30^{\circ} \mathrm{C}$ are comparable. The results of the present study concluded that the bioleaching can be a suitable alternative for conventional hydrominerological processing of low-grade copper ores.

Keywords: bioleaching, copper sulfide ore, chalcocite, covalite, acidophilic iron- and sulfur-oxidizing bacterium (Acidithiobacillus ferrooxidans)

\section{Introduction}

The impurities in valuable minerals in various geological settings have been a serious concern both in terms of value and environmental impact [1]. Globally, low-grade copper ores containing high oxides and carbonate gangue represents a major proportion of available resources of copper. The extraction of minerals from parent rock materials has been quite challenging owing to the complexity of refractory ores and high concentrations of associated impurities [2, 3]. These factors subsequently compromise overall operational efficiency of the conventional recovery processes. Under the notion of sustainability, environmental regulations and economic considerations, conventional metal recovery processes are less desired today in the mineral and mining industry [4]. The microbiological-driven processing of copper ores, technically bioleaching, under versatile geological settings has been considered an efficient technology on account of its economic and environmental benefits. The ferrous iron and sulfur oxidizing microorganisms are the main players for the bioleaching process. These microorganisms release the metals from the ores by a series of biochemical reactions in which sulfide minerals are oxidized to produce acidic species at the first stage, followed by acid consumption, ferric ion generation and ferric ion consumption respectively [5]. Different acidophilic iron- and sulfur-oxidizing bacteria have been previously known for their potential for bioleaching, such as Acidithiobacillus ferrooxidans, Acidithiobacillus caldus and Acidithiobacillus thiooxidans [6]. However, the bioprocess based on Acidithiobacillus ferrooxidans has been practiced in varying experimental settings such as stirred tank leaching and heap and dump leaching due to the ability of the bacterium to use various ions as an energy source [7-9]. A. ferrooxidans is a versatile chemolithotroph mostly isolated from acid mine drainage sites. Besides the potential role of A. ferrooxidans in bioleaching operations, this bacteria is known to contribute effectively in metals and sulfur recycling in the environment [10].

The bioleaching process is strongly associated with various intrinsic factors, including mineral composition of the parent rocks. On the other side, bacterial specie, the availability of nutrients for microbial growth, $\mathrm{pH}$, aeration, temperature and impurities affect mineral solubilization rates in a given bioleaching process [11, 12]. Among all aforesaid parameters, properties of minerals are of paramount importance. Wu et al. [8] reported preferential leaching rates of different sulfide minerals treated with bacteria. These materials include chalcopyrite, covellite, enargite, chalcocite and bornite. Besides a vast disparity in composition of rocks, biohydrometallurgy proved to be a high throughput approach and economically viable option as compared to the pyrometallurgic processing, allowing for robust extraction from low-grade and relatively complex copper ores that otherwise would be considered waste [11, 13].

The Reko Diq mines in a desert area of Changi District, Balochistan, are in close proximity to the Pakistani-Afghan-Iranian border. According to geological survey, Reko Diq represents one of the largest copper reserves in the world, having estimated deposits of 5.9 billion tons of ore-grade $0.41 \%$ copper [14]. Based on different exploration projects carried out between 1933-1997, 48 pockets have been identified for the extraction of copper and gold from the Reko Diq mine complex [15]. The extraction of minerals from rock materials is a laborious process involving a number of technical steps. As mentioned, the recovery rate obtained by conventional processing methods from Reko Diq geological settings is only $0.41 \%$, producing $5.3 \mathrm{pc}$ of grade copper [16]. Bioleaching could be an alternative and economically more attractive approach for the extraction of valuable minerals from this site. It is likely that the application of microbial-enhanced extraction of copper could transform Reko Diq mineral resources into more profitable reserves. Various efforts have been made to evaluate different process parameters. Nevertheless, the microbiology of heap bioreactors remained unclear due to the complexity of microbial systems and their working efficiency under experimental conditions. The present research typically focused on analyzing the mineral composition of Reko Diq ores and isolating acidophilic iron and sulfuroxidizing bacterium for application in bioleaching of low-grade copper ore.

\section{Material and Methods}

\section{Collection of Copper Ore Samples}

A Reko Diq copper ore sample $(50 \mathrm{Kg})$ was received from the Liaison Office, Baluchistan Copper Gold Project (BCGP), Islamabad, for the present studies. The sample was mixed thoroughly with repeated coning and quartering techniques and at last a representative copper ore sample of about $1 \mathrm{~kg}$ was prepared with the help of a laboratory sample divider. The representative ore sample was ground to fine powder to pass through a 200-mesh 
particle size test sieve $(<74 \mu \mathrm{m})$ by using a vibrating cup mill for mineralogical and chemical analyses and present bacterial leaching studies.

\section{X-ray Diffraction Analysis of Reko Diq Ore Sample}

X-ray diffraction (XRD) techniques were carried out for mineralogical analysis of the copper ore sample. XRD analysis of the top fill fine particles mount was done by using $\mathrm{CuK} \alpha$-radiation (1.54056 $\AA$ ) and a vertical broad range goniometer equipped with diffracted ray monochromator. The black shale specimen was scanned from $3^{\circ} 2 \Theta$ to $70^{\circ} 2 \Theta$ in increments of $0.02^{\circ}$ by 0.5 -seconds step time. The matching of X-ray diffractogram was carried out in a JCPDS powder diffraction library in an automatic mode, and for conformation it was checked manually against the automated identification of phases.

\section{Preparing Culture Media}

For the isolation of required chemolithotroph from the acid water samples, a previously reported $9 \mathrm{~K}$ basal salt media was used with the following composition of salts $(\mathrm{g} / \mathrm{L}):\left(\mathrm{NH}_{4}\right)_{2} \mathrm{SO}_{4} 3 \mathrm{~g}, \mathrm{KCl} 0.1 \mathrm{~g}, \mathrm{~K}_{2} \mathrm{HPO}_{4} 0.5 \mathrm{~g}$, $\mathrm{MgSO}_{4} .7 \mathrm{H}_{2} \mathrm{O} 0.5 \mathrm{~g}$, and $\mathrm{Ca}\left(\mathrm{NO}_{3}\right)_{2} 0.01 \mathrm{~g}$. The $\mathrm{pH}$ of the medium was adjusted to 2.0 using $5 \mathrm{M} \mathrm{H}_{2} \mathrm{SO}_{4}$. After sterilization, the media was supplemented with $44.7 \mathrm{~g} / \mathrm{L}$ sterilized ferrous iron (9K-Fe) and $19 \mathrm{~g} / \mathrm{L}$ heat-sterilized sulfur to make $9 \mathrm{~K}-\mathrm{S}$ media. These culture media were used for enrichment and submerged fermentation [17].

The 9K Gelrite-Fe solid medium was used for the isolation and enumeration of acidophilic iron and sulfur oxidation. Briefly, $4.0 \mathrm{~g}$ of Gelrite was soaked in $300 \mathrm{~mL}$ distilled water for 20 minutes and then autoclaved and mixed with the previously mentioned 9K-Fe and 9K-S media.

\section{Enrichment and Isolation of Iron- and Sulfate-Oxidizing Bacteria}

The acidic bed-rock seepage water samples from different sites of black shale deposit of Diameer District, KPK were collected in pre-sterilized bottles. The isolation of $A$. ferrooxidans was carried out by taking 1-liter of bedrock seepage water filtrate. After filtration, the membrane filter was positioned in a conical flask containing 20-ml sterilized water of $\mathrm{pH} 2.5$ and incubated in a shaking incubator at $30^{\circ} \mathrm{C}$ for $1 \mathrm{hr}$ to liberate the bacterial cells attached on a membrane filter. From this, 0.1-mL of the suspension was spread onto 9K Gelrite $\mathrm{FeSO}_{4}$ solid medium incubated for 2 weeks to get bacterial growth. A single colony was packed into $50 \mathrm{~mL}$ 9K-Fe liquid medium and incubated till the medium color changed to brick red, indicating oxidation of ferrous iron. From this, $0.1 \mathrm{~mL}$ culture broth was re-spread onto Gelrite 9K-Fe solid medium to obtain the pure culture. The pure isolate was obtained after five to six sequential re-spreadings and named strain BSTFe-2.

\author{
Morphology and Physiology of \\ the Strain BSTFe-2
}

The cells of bacterial strain having the ability of iron-oxidation were observed under a phase contrast microscope to examine cell size, shape and motility. The growth pattern of the bacteria was determined in $9 \mathrm{~K}-\mathrm{Fe}$ liquid medium under the effect of varying $\mathrm{pH}$ levels and temperatures. For evaluating optimum $\mathrm{pH}, 1 \mathrm{~mL}$ of the growing culture of the strain BSTFe-2 was inoculated into $100 \mathrm{~mL}$ flasks containing $9 \mathrm{~K}-\mathrm{Fe}$ broth and incubated at $30^{\circ} \mathrm{C}$ in an orbital shaker and standard inoculums with approx. $10^{9}$ cells per $\mathrm{ml}$ used in all experiments. Whereas for determining optimum growth temperature, aforesaid conditions were set at different temperatures (between $15-50^{\circ} \mathrm{C}$ ). The growth of bacteria (direct cell count) was monitored using a Petroff-Hausser chamber at different time intervals during 6-8 days of the incubation period. The $\mathrm{pH}$ of the fermentation broth during the growth of bacteria was monitored using a digital $\mathrm{pH}$ meter. Titration method as described in [18] using $\mathrm{K}_{2} \mathrm{Cr}_{2} \mathrm{O}_{7}$ with a diphenylamine as the indicator was employed to determined iron concentration. The concentration of sulfate in $9 \mathrm{~K}-\mathrm{S}$ medium was calculated by barium sulfate turbidimetry [19].

\section{Shake Flask Bioleaching Studies of Copper Ore}

Shake flask leaching experimentation was done in a 250-ml Erlenmeyer flask (150 rev/ min) with copper ore in $9 \mathrm{~K}$ mineral salt solution. The starting $\mathrm{pH} 2.5$ of leach slurry was maintained with $5 \mathrm{M} \mathrm{H}_{2} \mathrm{SO}_{4}$ or $\mathrm{NaOH}$ solution. The inoculated flasks were made with $5-\mathrm{ml}$ inoculums containing about $10^{9}$ cells $/ \mathrm{ml}$ of locally isolated strain of acidophilic iron- and sulfur-oxidizing bacterium. In chemical (sterile) controls, thymol $(0.08 \% \mathrm{wt} / \mathrm{vol}$ final concentration) dissolved in ethanol were included in each experiment. The effect of acid concentration, pulp density and leaching time on $\mathrm{Cu}$ solubilization from ore were studied in shake flask leaching experiments. Periodically, leach liquor samples were aseptically taken for monitoring $\mathrm{pH}$, redox potential (Eh) and the analysis soluble copper in leach solutions. Copper and associated metals in ore and leach solution were analyzed by standard atomic absorption spectrometry (Varian Model SpectrAA 30/40AAS) as well as induced coupled plasma optical emission spectrometry (iCAP 6500 Thermo Fisher Scientific, USA).

\section{Results and Discussion}

\section{Analysis of Reko Diq Copper Ore}

In order to characterize the different proportion of each mineral phase in the copper ore sample, X-ray diffraction (XRD) analysis of top fill mixture mount was performed. The minerals identified were quartz, 


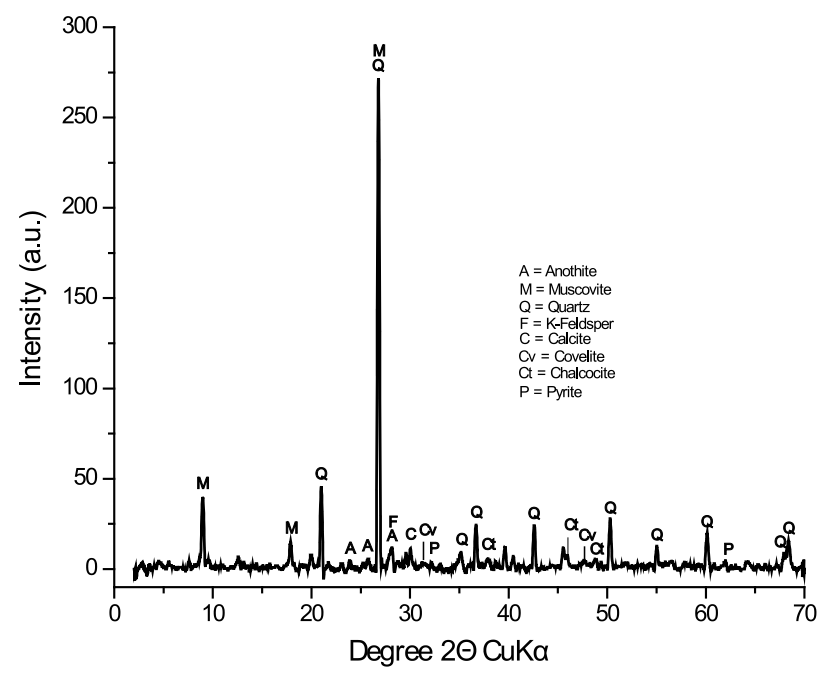

Fig. 1. XRD diffractogram of Reko Diq copper ore sample with symbol designation: $\mathrm{A}=$ anorthite, $\mathrm{C}=$ calcite, $\mathrm{Cv}=$ covellite, $\mathrm{Ct}=$ chalcocite, $\mathrm{F}=\mathrm{K}$-feldspar, $\mathrm{M}=$ Muscovite, $\mathrm{P}=$ pyrite, $\mathrm{Q}=$ quartz.

muscovite (a dioctahedral mica-mineral), anorthite (Ca-feldspar), microcline (K-feldspar), calcite, pyrite, covellite and chalcocite. XRD diffractogram of the copper ore sample is shown in Fig. 1.

Quartz $\left(\mathrm{SiO}_{2}\right)$ was the major mineral existing in the copper ore sample. Quartz, muscovite, microcline, and

Table 1. Chemical analysis of Reko Diq copper ore sample.

\begin{tabular}{|c|c|}
\hline Constituents & Results (\%) \\
\hline $\mathrm{SiO}_{2}$ & 58.70 \\
\hline $\mathrm{Al}_{2} \mathrm{O}_{3}$ & 17.71 \\
\hline $\mathrm{Fe}_{2} \mathrm{O}_{3}$ & 6.72 \\
\hline $\mathrm{CaO}$ & 1.08 \\
\hline $\mathrm{CuO}$ & $1.015(0.81 \% \mathrm{Cu})$ \\
\hline $\mathrm{MgO}$ & 0.913 \\
\hline $\mathrm{P}_{2} \mathrm{O}_{5}$ & 1.798 \\
\hline $\mathrm{MnO}_{2}$ & 0.041 \\
\hline $\mathrm{Cr}_{2} \mathrm{O}_{3}$ & 0.021 \\
\hline $\mathrm{Na}_{2} \mathrm{O}$ & 0.295 \\
\hline $\mathrm{K}_{2} \mathrm{O}$ & 1.419 \\
\hline $\mathrm{BaO}$ & 0.025 \\
\hline $\mathrm{SnO}_{2}$ & 0.054 \\
\hline $\mathrm{S}$ & 3.195 \\
\hline $\mathrm{TiO}_{2}$ & 0.370 \\
\hline $\mathrm{V}_{2} \mathrm{O}_{5}$ & 0.012 \\
\hline $\mathrm{ZnO}$ & 0.011 \\
\hline Loss on ignition at $1000^{\circ} \mathrm{C}$ & 5.41 \\
\hline
\end{tabular}

anorthite were the main silicate-phases present in the ore sample. Covellite $(\mathrm{CuS})$ and chalcocite $\left(\mathrm{Cu}_{2} \mathrm{~S}\right)$ were the main copper minerals identified in the ore matrix. Both these $\mathrm{Cu}$-sulfide minerals are known as secondary copper sulfide minerals in nature. Pyrite $\left(\mathrm{FeS}_{2}\right)$ was also identified as an iron sulfide mineral in the ore-matrix by the XRD analysis. Calcite $\left(\mathrm{CaCO}_{3}\right)$ was present as a main acid-consuming gangue mineral. X-ray diffraction provide a comprehensive analysis of the minerals and have been employed extensively for compositional analysis of different copper ores [20, 21].

The chemical analysis of the copper ore sample is presented in Table 1.

The ore sample contained $1.02 \% \mathrm{CuO}(0.81 \% \mathrm{Cu})$ on a dry matter basis. The ore sample also contained $58.72 \% \mathrm{SiO}_{2}, 17.71 \% \mathrm{Al}_{2} \mathrm{O}_{3}$ and $6.72 \% \mathrm{Fe}_{2} \mathrm{O}_{3}$ as major constituents present in the ore matrix. In addition, alkali and alkaline earth metals like $\mathrm{Na}, \mathrm{K}, \mathrm{Ca}, \mathrm{Ba}$ and $\mathrm{Mg}$ with some toxic metals ( $\mathrm{Cr}$ and $\mathrm{Sn}$ ) were also present in the ore sample. Manganese (Mn) and phosphorus (P) contents of the ore were found to be $0.041 \% \mathrm{MnO}_{2}$ and $1.798 \% \mathrm{P}_{2} \mathrm{O}_{5}$. The sulfur (S) content of $3.195 \%$ analyzed in the ore sample was the main constituent of covellite $(\mathrm{CuS})$, chalcocite $\left(\mathrm{Cu}_{2} \mathrm{~S}\right)$ and pyrite $\left(\mathrm{FeS}_{2}\right)$ present in the ore sample. The disparity in the chemical composition of various ore samples is typically associated with the geographic location of the reservoir and pattern of rock formation $[22,23]$.

\section{Isolation of the Bacterial Strain}

The isolation of iron and sulfate-oxidizing bacterial strain was carried out from acid water samples. After enrichment in $9 \mathrm{~K}-\mathrm{Fe}$ liquid medium, bacterial colonies were obtained on plates containing Gelrite 9K-Fe solid media. Reddish-brown colonies of iron-oxidizing bacteria appeared on the agar plates after one-week incubation at $30^{\circ} \mathrm{C}$ (Fig. 2). Each single colony was picked and cultivated in liquid iron medium $\left(9 \mathrm{KFe}^{2+}\right)$

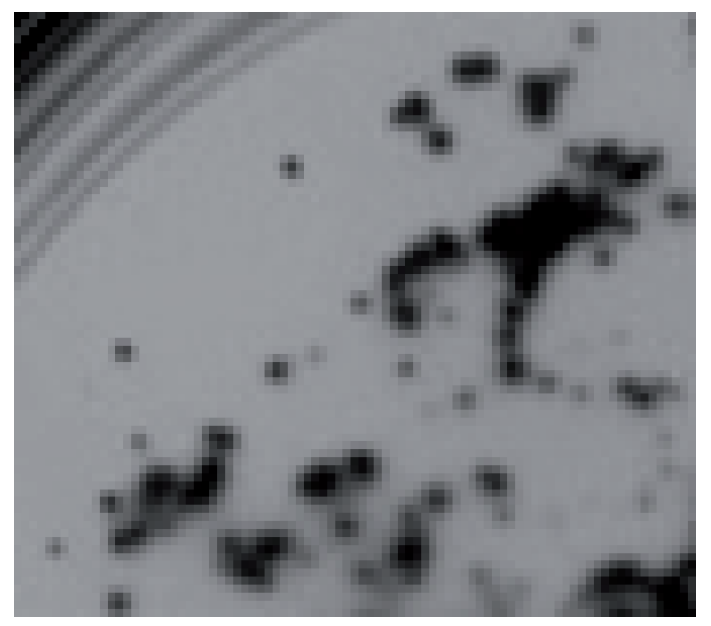

Fig. 2. Deep brown colonies of enriched culture of strain BSTF-2 on solid Gelrite $\mathrm{K} 9-\mathrm{FeSO}_{4}$ medium. 


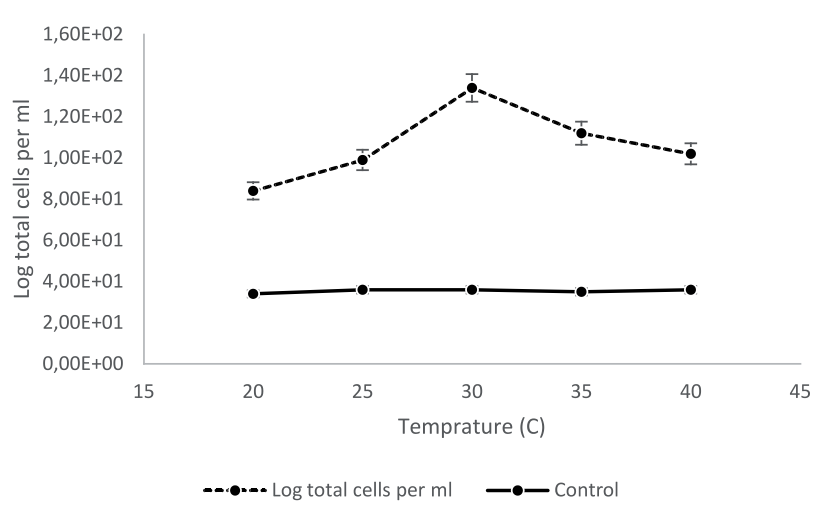

Fig. 3. Optimization of temperature for strain BSTF-2.

of $\mathrm{pH}$ 2.0. Under continuous shaking conditions, the cultures were grown for 5 days at $30^{\circ} \mathrm{C}$ and the medium turned reddish-brown after 4 weeks of incubation, indicating the biochemical transformation of $\mathrm{Fe}^{2+}$ to $\mathrm{Fe}^{3+}$. The harvested cells of iron-oxidizing bacteria were inoculated onto solid Gelrite-FeSO 4 plates. In modified Gelrite $9 \mathrm{~K}-\mathrm{Fe}$ - solid medium, gellan gum was used instead of agar for solidification and supporting growth of bacterial strains. It has been reported frequently in the literature that the chemoautotrophs show considerable sensitivity to organic compounds, including polysaccharide in agar. Moreover, galactose found in agar has an inhibitory effect on the growth of $A$. ferrooxidans [24]. The addition of gelrite instead of agar was quite promising owing to its ability to form clear and rigid gels in the presence of cations, compatibility with various nutrients and thermal stability $[25,26]$. Colonies of enriched isolated strain of acidophilic iron-oxidizing bacterium on Gelrite$\mathrm{FeSO}_{4}$ plates were minute $(0.2-0.7 \mathrm{~mm})$, circular, and entire. The phase-contrast microscopic observations of isolated strains of acidophilic iron- and sulfur-oxidizer resembling Acidithiobacillus ferrooxidans (designated as BSTF-2) was motile, single rod-shaped and Gramnegative bacterium (Fig. 2).

The isolated strain (BSTF-2) oxidized $\mathrm{Fe}^{2+}$ to $\mathrm{Fe}^{3+}$, pyrite, sulfur and reduced sulfur-compounds like sodium thiosulfate $\left(\mathrm{Na}_{2} \mathrm{~S}_{2} \mathrm{O}_{3}\right)$ and potassium tetrathionate



Fig. 4. Optimization of incubation time for strain BSTF-2.

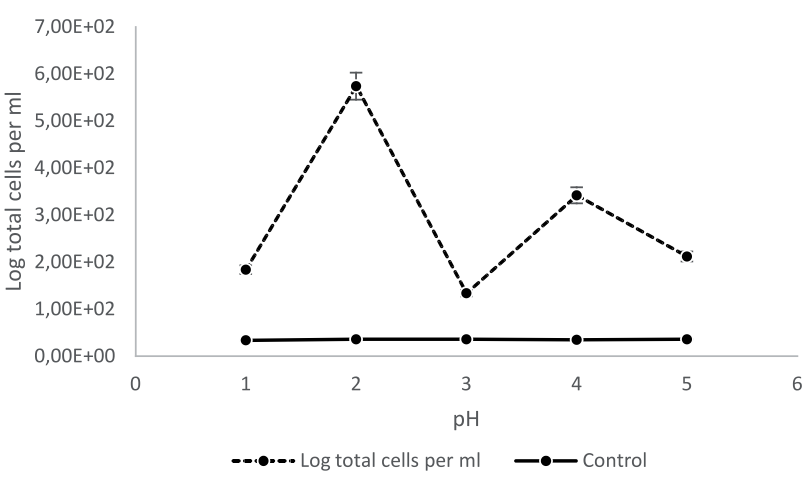

Fig. 5. pH Optimization for strain BSTF-2.

$\left(\mathrm{K}_{2} \mathrm{~S}_{4} \mathrm{O}_{6}\right)$. Similar results have been previously reported by Zhang et al. [9, 27].

\section{Optimum Growth Conditions for Strain BSTF-2}

Although the strain BSTF-2 isolated from the acid water was found to be mesophilic in nature, it showed the ability to survive between 20 to $40^{\circ} \mathrm{C}$ with an optimum growth temperature of $30^{\circ} \mathrm{C}$ (Fig. 3).

Maximum growth was observed between the $3^{\text {rd }}$ and $4^{\text {th }}$ days of incubation (Fig. 4).

The optimum $\mathrm{pH}$ for the growth of strain BSTF-2 was found to be $\mathrm{pH} 2$ (Fig. 5). After this $\mathrm{pH}$ a sharp decline in the growth of $A$. ferrooxidans was observed. However, interestingly, at $\mathrm{pH} \mathrm{4,} \mathrm{a} \mathrm{mild} \mathrm{increase} \mathrm{in} \mathrm{the}$ bacterial growth was observed.

It is possible that between $\mathrm{pH} 2$ and 4, the decrease in the growth $(\mathrm{pH} \mathrm{3)}$ was due to some intermediate compounds generated because of mineral decomposition.



Fig. 6. a) $\mathrm{pH}$ and b) redox potential profiles of leach solutions obtained from various pulp densities of copper ore with isolated strain of acidophilic iron- and sulfur-oxidizing bacteria; symbol designations: $\square=$ control $5 \%(\mathrm{w} / \mathrm{v}), \square=$ inoculated $5 \%(\mathrm{w} / \mathrm{v})$, $\triangle=$ control $10 \%(\mathrm{w} / \mathrm{v}), \boldsymbol{\Delta}=$ inoculated $10 \%(\mathrm{w} / \mathrm{v}), \bigcirc=$ control $20 \%(\mathrm{w} / \mathrm{v})$ and - inoculated $20 \%(\mathrm{w} / \mathrm{v})$. 
At further increase in $\mathrm{pH}$, these intermediate compounds could have been converted into less toxic species and favored the growth of $A$. ferrooxidans [28]. We previously reported that the optimum temperature for the growth of $A$. ferrooxidans was $30^{\circ} \mathrm{C}$ and at $\mathrm{pH} 2$ the bacterium showed maximum growth and biochemical activities [11]

\section{Bioleaching of Copper Ore}

Shake flasks leaching experiments were carried out to investigate the possibility of copper bioleaching from Reko Diq ore using an isolated strain of acidophilic iron-oxidizing bacterium (BSTFe-2). In the leaching process, 9K mineral salts medium of initial $\mathrm{pH} 2.5$ containing copper ore $(1 \% \mathrm{wt} / \mathrm{vol}$. ore pulp density) was investigated at $30^{\circ} \mathrm{C}$ under shaking conditions (Fig. 6).

During the leaching process, a drastic change in the initial $\mathrm{pH}$ and redox potential (Eh) of leach solutions was observed. According to some previous reports $[29,30]$ the drop in $\mathrm{pH}$ could be due to the production of sulfuric acid in the medium as a result of bacterial oxidation of pyrite. After 30 days of leaching, about $95 \%$ of $\mathrm{Cu}$ was solubilized from the ore using Acidithiobacillus ferrooxidans strain BSTFe-2, which is comparatively higher than those reported earlier $[31,32]$. Previously, 50 to $90 \%$ leaching efficiencies have been reported using iron- and sulfur-oxidizing bacteria. The differences in results are largely attributed to the quality and composition of the refectory ores $[1,33,34]$. Nonetheless, it is generally believed that the acidic environment (i.e., low $\mathrm{pH} 1.2$ to 1.5 and high redox potential of $651 \mathrm{mV}$ to $705 \mathrm{mV}$ ) facilitates copper dissolution from the chalcocite mineral [35]. The oxidative leaching process is sensitive to redox potential, and higher copper dissolution rate has been achieved at redox potential of $450-650 \mathrm{mV}$ [36]. The present study is in line with aforesaid results that the bioleaching of copper is a function of acidic $\mathrm{pH}$ and redox potential of the medium.



Fig. 7. Copper solubilized from ore at various pulp densities by isolated strain of acidophilic iron- and sulfur-oxidizing bacteria during 30 days of leaching time.

\section{Effect of Ore Pulp Density on Copper Bioleaching from Ore}

To investigate the role of pulp density (solid-to-liquid ratio) on the bioleaching process, shake flasks leaching experiments were performed with 5, 10 and 20\% pulp densities (wt/vol). The results indicated that there was a marked change in the medium $\mathrm{pH}$ from 2.5 to 1.1 , indicating biochemical activity of inoculated bacteria (Fig. 7).

Possibly, this drop in $\mathrm{pH}$ in medium was due to the biological generation of $\mathrm{H}_{2} \mathrm{SO}_{4}$ by the bacterial oxidation of pyrite; it was also observed that there was a drop in $\mathrm{pH}$ of the media by increasing pulp density (solid to liquid ratio)

At pulp densities of 5, 10 and $20 \%(\mathrm{w} / \mathrm{v})$, the $\mathrm{pH}$ of the leach suspensions was 1.64, $\mathrm{pH} 1.46$ and $\mathrm{pH}$ 1.23, respectively, after 30 days of incubation (Fig. 8). It could be suggested that sulfuric acid was biologically generated at a high concentration in the media as the solid to liquid increased.

This could be a logical reason for improved contents of pyrite in the media leading to increased pulp density during the bioleaching process. The interpretation of the data suggested that with an increase in ore pulp density, there was a decrease in $\mathrm{Cu}$ solubilization from copper ore. It has been reported that for gaining higher yield of copper from the ores, pulp density must be optimized [2, 37].

\section{Conclusions}

The main objective of the present study was to "eco-efficient" exploitation of the Reko Diq copper ore deposit for the extraction of copper. A special emphasis focused on the bioleaching of copper ore with isolated strain of acidophilic iron- and sulfur-oxidizing bacteria on dissolution of $\mathrm{Cu}$ during shake flasks studies. Bioleaching tests have shown that the copper ore was amenable to the leaching process regarding pyrite oxidation. The results of this study are very encouraging and can be useful for scientists, process engineers, geologists, and technical managers.

\section{Acknowledgements}

Authors extend their appreciation to the Deanship of Scientific Research at King Khalid University for funding this work through research groups program under Grant No. R.G.P-2/49/40

\section{Conflict of Interest}

The authors declare no conflict of interest. 


\section{References}

1. PANDA S., AKCIL A., PRADHAN N., DEVECI H. Current scenario of chalcopyrite bioleaching: a review on the recent advances to its heap-leach technology. Bioresour. Technol. 196, 694, 2015.

2. LOTFALIAN M., RANJBAR M., FAZAELIPOOR M., SCHAFFIE M., MANAFI Z. Continuous Bioleaching of Chalcopyritic Concentrate at High Pulp Density. Geomicrobiolo J. 32, 42, 2015.

3. OKIBE N., GERICKE M., HALLBERG K.B., JOHNSON D.B. Enumeration and characterization of acidophilic microorganisms isolated from a pilot plant stirred-tank bioleaching operation. App. Environ. Microbiol. 69, 1936, 2003.

4. PETERSEN J. Heap leaching as a key technology for recovery of values from low-grade ores - A brief overview. Hydrometallurgy. 161 (1), 206, 2015.

5. YANG Y., DIAO M., LIU K., QIAN L., NGUYEN A.V., QIU G. Column bioleaching of low-grade copper ore by Acidithiobacillus ferrooxidans in pure and mixed cultures with a heterotrophic acidophile Acidiphilium sp. Hydrometallurgy. 93 (8) 131,2013.

6. ZHANG Y., YANG Y., LIU J., QIU G. Isolation and characterization of Acidithiobacillus ferrooxidans strain QXS-1 capable of unusual ferrous iron and sulfur utilization. Hydrometallurgy. 136, 51, 2013.

7. BOXALL N., REA S., LI J., MORRIS C., KAKSONEN A. Effect of high sulfate concentrations on chalcopyrite bioleaching and molecular characterisation of the bioleaching microbial community. Hydrometallurgy. 168 32, 2016.

8. FENG S., YANG H., WANG W. Insights to the effects of free cells on community structure of attached cells and chalcopyrite bioleaching during different stages. Bioresour. Technol. 200,186, 2016.

9. ZHANG R., WEI D., SHEN Y., LIU W., LU T., HAN C. Catalytic effect of polyethylene glycol on sulfur oxidation in chalcopyrite bioleaching by Acidithiobacillus ferrooxidans. Miner. Eng. 95, 74, 2016.

10. VALDÉS J., PEDROSO I., QUATRINI R., DODSON R.J., TETTELIN H., BLAKE R., EISEN J.A., HOLMES D.S. Acidithiobacillus ferrooxidans metabolism: from genome sequence to industrial applications. BMC Genomics. 9, 597, 2008.

11. FU K., NING Y., CHEN S., WANG Z. Bioleaching of different copper sulphide minerals and their physicochemical properties dependence. Miner. Process. Extr. Metall. Rev. 125, 1, 2016.

12. HAGHSHENAS D.F., BONAKDARPOUR B., ALAMDARI E.K., NASERNEJAD B. Optimization of physicochemical parameters for bioleaching of sphalerite by Acidithiobacillus ferrooxidans using shaking bioreactors. Hydrometallurgy. 111, 22, 2012.

13. WANG Y., SU L., ZHANG L., ZENG W., WU J., WAN L., QIU G., CHEN X., ZHOU H. Bioleaching of chalcopyrite by defined mixed moderately thermophilic consortium including a marine acidophilic halotolerant bacterium. Bioresour. Technol. 121, 348, 2012.

14. SYKES J.P. Using the Oxford Scenarios deductive methodology to understand the long-term future of copper mining and guide minerals exploration targeting strategies. 10.13140/RG.2.2.16180.86402, 2015.

15. WAGNER D., DISPARTE D. Economic and Resource Nationalism. Global Risk Agility and Decision Making: Springer. 145, 2016.
16. SIDDIQI F.H. The Political Economy of the Ethnonationalist Uprising in Pakistani Balochistan, 1999-2013. The political economy of conflict in South Asia: Springer. 57, 2015

17. SILVERMAN M.P., LUNDGREN D.G. Studies on the chemoautotrophic iron bacterium ferrobacillus ferrooxidans ii.: Manometric Studies. J. Bacteriol. 78, 326, 1959.

18. MENDHAM J. Vogels textbook of quantitative chemical analysis: Pearson Education India; 2006.

19. CHESNIN L., YIEN C. Turbidimetric determination of available sulfates. Soil Sci. Soc. Am. J. 15,149, 1951.

20. DALM M., BUXTON M.W., VAN RUITENBEEK F.J., VONCKEN J.H. Application of near-infrared spectroscopy to sensor based sorting of a porphyry copper ore. Miner. Eng. 58, 7, 2014.

21. WATLING H., COLLINSON D., LI J., MUTCH L., PERROT F., REA S., REITH F., WATKIN E. Bioleaching of a low-grade copper ore, linking leach chemistry and microbiology. Miner. Eng. 56, 35, 2014.

22. FAN X., MU D., YI J., WANG H., LUO W. Sourcing copper ores for production of bronzes excavated at Shuangyantang, a Western Zhou (1046-771 bc) site in Chongqing (Southwest China): evidence from lead isotope analysis. Archaeol. Anthropol. Sci. 8, 197, 2016.

23. CHEN W.T., ZHOU M.-F., LI X., GAO J.-F., HOU K. In-situ LA-ICP-MS trace elemental analyses of magnetite: $\mathrm{Cu}-(\mathrm{Au}, \mathrm{Fe})$ deposits in the Khetri copper belt in Rajasthan Province, NW India. Ore Geol. Rev. 65, 929, 2015.

24. TUOVINEN O.H., KELLY D.P. Studies on the growth of Thiobacillus ferrooxidans. Archiv für Mikrobiologie. 88, 285, 1973.

25. MISHRA A.K., ROY P. A note on the growth of Thiobacillus ferrooxidans on solid medium. J. App. Bacteriol. 47, 289, 1979.

26. SHUNGU D., VALIANT M., TUTLANE V., WEINBERG E., WEISSBERGER B., KOUPAL L., GADEBUSCH $\mathrm{H}$, STAPLEY E. Gelrite as an agar substitute in bacteriological media. App. Environ. Microbiol. 46, 840, 1983.

27. LI L., LV Z., YUAN X. Effect of L-glycine on bioleaching of collophanite by Acidithiobacillus ferrooxidans. Int. Biodeter. Biodegrad. 85, 156, 2013.

28. JENSEN A.B., WEBB C. Ferrous sulphate oxidation using Thiobacillus ferrooxidans: a review. Process biochem. 30, 225, 1995.

29. YU R., SHI L., GU G., ZHOU D., YOU L., CHEN M., QIU G., ZENG W. The shift of microbial community under the adjustment of initial and processing $\mathrm{pH}$ during bioleaching of chalcopyrite concentrate by moderate thermophiles. Bioresour. Technol. 162, 300, 2014.

30. WANG J., ZHU S., ZHANG Y.-S., ZHAO H.-B., HU M.-H., YANG C.-R., QIN W.-Q., QIU G.-Z. Bioleaching of low-grade copper sulfide ores by Acidithiobacillus ferrooxidans and Acidithiobacillus thiooxidans. J. Cent. South Univ. 21, 728, 2014.

31. SUGIO T., DE LOS SANTOS S.F., HIROSE T., INAGAKI K., TANO T. The mechanism of copper leaching by intact cells of Thiobacillus ferrooxidans. Agri. Bio. Chem. 54, 2293, 1990.

32. LIZAMA H.M., SUZUKI I. Bacterial leaching of a sulfide ore by Thiobacillus ferrooxidans and Thiobacillus thiooxidans: I. Shake flask studies. Biotechnol. Bioeng. 32, $110,1988$.

33. LUIS S.-M., LUIS R.-O., HANS C.-G., VLADIMIR A.-A. Bioleaching of copper sulphide ore by a microbial 
consortium isolated from acid mine drainage: Influence of [Fe 2]. Adv. Mater. Res. 1130, 2015.

34. ZHAO H.-B., JUN W., QIN W.-Q., ZHENG X.-H., LANG T., GAN X.-W., QIU G.-Z. Surface species of chalcopyrite during bioleaching by moderately thermophilic bacteria. Trans. Nonferrous Met. Soc. China. 25, 2725, 2015.

35. RAMANATHAN T., TING Y.-P. Selective Copper Bioleaching by Pure and Mixed Cultures of Alkaliphilic Bacteria Isolated from a Fly Ash Landfill Site. Water Air Soil Pollut. 226, 1, 2015.
36. ZHAO H., WANG J., YANG C., HU M., GAN X., TAO L., QIN W., QIU G. Effect of redox potential on bioleaching of chalcopyrite by moderately thermophilic bacteria: an emphasis on solution compositions. Hydrometallurgy. 151, 141, 2015.

37. LOTFALIAN M., RANJBAR M., FAZAELIPOOR M., SCHAFFIE M., MANAFI Z. The effect of redox control on the continuous bioleaching of chalcopyrite concentrate. Miner. Eng. 81, 52, 2015. 